WCP 2008 Proceedings

Vol.40 Philosophy of Law

\title{
From below to above Rawls on just war
}

\author{
Asger Sørensen \\ University of Aarhus, Denmark \\ aso@dpu.dk
}

ABSTRACT From A Theory of Justice to The Law of Peoples Rawls's liberalism develops from individualism to a kind of communitarianism. This apparently makes him blind to conflicts between the individual and the collective, and the resulting position contributes to change his perspective on just war. From a duty to prevent war by civil disobedience he develops a duty to initiate war because of human right violations, and this must be criticized.

$\mathbf{0 .}$

In a recent and comprehensive volume on Rawls's The Law of Peoples $(L P)^{1}$ his 'just war theory' is acknowledged to deserve a closer scrutiny. ${ }^{2}$

${ }^{1}$ John Rawls: The Law of Peoples, Cambridge, Mass.: Harvard University Press, 1999.

${ }^{2}$ Cf. R. Martin \& D.A. Reidy: "Introduction', in Martin \& Reidy (eds.): Rawls's Law of Peoples. A Realistic Utopia?, Oxford: Blackwell, 2006, pp. $11 \mathrm{f..}$ 
Rawls supports the idea of just war already in $A$ Theory of Justice $(T o)^{3}$, but in a rather different context. The critique of his late position in $L P$ will be based on an analysis of the early position.

1.

In Political liberalism $(P L)^{4}$ Rawls underlines that in ToJ he did not distinguish between 'political' and 'comprehensive' doctrines ( $P L$ xviii). The discussion of justice in terms of utilitarianism $v$. deontology in ToJ indicates an ethical perspective, and this is confirmed by the treatment of just war. The context of discussion is the possibility of a justification for civil disobedience, first, the refusal of individuals to carry out certain acts of war with reference to jus in bello and, second, the conscientious refusal to participate in war with reference to jus ad bellum (ToJ 331). This justification is according to Rawls to be conceived of in political terms with reference to justice as fairness, but still the point of departure is one individual person confronting a problem or dilemma, i.e. a classical ethical situation.

When it comes to the first, the refusal to carry out certain acts of war, Rawls simply makes it legitimate for a soldier to act in accordance with his "natural duty' and not his 'duty to obey'. When it comes to refusal to participate in war Rawls is more subtle. On the one hand he admits that conscription is permissible, if it is demanded for the defence of liberty, wherever it might be threatened (ToJ $\S 58,334)$, that is, not just at home in the US, but by implication also in Korea or Vietnam. Just war in then possible, and that brings him on line with official cold war ideology of that time.

On the other hand, Rawls says that if the objective of a war is economic advantage or national power, which infringes the liberty of

${ }^{3}$ John Rawls: A Theory of Justice, revised ed., Cambridge, Mass.: Harvard University Press, 1999.

${ }^{4}$ John Rawls: Political Liberalism, paperback ed., New York: Columbia University Press, 1996. 
other peoples, then citizens have the right to decline doing their military service. And even more, if the aims of the conflict are dubious, one may have the 'duty and not only the right to refuse' (ToJ 335). Given the 'often predatory character of state power' civil disobedience against conscription can contribute to making unjust wars impossible. Still, what is needed according to Rawls is not general pacifism, rather 'a discriminating conscientious refusal to engage in war in certain circumstances'.

The principles that can justify civil disobedience are in both cases for Rawls simply familiar and well acknowledged principles of international law, but these principles must in turn be justified by considering nations as the parties in the original position restricted by the veil of ignorance regarding their power and strength. However, even though the original position is thought of as applicable to nations and the justification of their foreign policy, Rawls' main concern is clearly to justify disobedience to the state, and the primary parties involved in the original position are the soldier and the citizen, not the nation. The sovereignty rest in the people as a sum of individual citizens, which means that political legitimacy comes from below, and that the state is never legitimate in itself.

2.

This is not as clearly the case in the political doctrine of $P L$ and $L P$. Like ToJ the ideal for $P L$ is a liberal society, and in $P L$ this means respect for the political doctrine of liberalism and the ideals of an overlapping consensus of reasonable comprehensive doctrines. Rawls still thinks of states as repressive, although now also necessary to uphold a community, which shares a comprehensive doctrine ( $P L$ 37). But there is no mention in $P L$ of the moral duty sometimes to disobey those in command so carefully spelled out in ToJ, and the reason may be found in his new normative perspective, which is very similar to communitarianism. From the clearly individual and anti-authoritarian 


\section{Philosophy of Law}

normative perspective from below in ToJ, in $P L$ the normative perspective is collective and from above, even though it is not clear, what is at the top, since the state cannot be a normative ideal.

People are the basic political entity in $L P$, but hardly mentioned in $T o J$ or PL. In ToJ Rawls talks indiscriminately of 'state' and 'nation', but in $L P$ he clearly distinguishes between the two ( $L P 25$ ), and it is from the concept of 'nation' that he develops his concept of 'people' as a cultural unity united by common sympathies. Such 'peoples' have governments, and the power of governments and thus states are limited by the power of the peoples, which in turn must be in accordance with the law of peoples' ( $L P$ 26). According to Rawls the principles in $L P$ should govern international relations whether the peoples are united by a state or not; people are the basic entity, which should count in international law, not the state.

Like a nation or a community the people is a collective unity, not a collection of liberal individuals with natural rights and duties. Even though Rawls separates state and people, both terms signify holistic entities and making this a norm for the conceptually ideal society apparently makes him conceptually blind to the possible conflicts between individuals and people.

The liberalism expressed in $L P$ is thus very different from the one in ToJ; the latter is closer to what is denounced in $P L$ as libertarianism ( $P L$ lviii).

3.

These displacements are only implicit when Rawls relates $L P$ to his earlier works. First $L P$ is characterized as a development of the indication in ToJ of how to apply 'justice as fairness' to international law ( $L P 4$ ), and as such the doctrine must be considered both political and comprehensive. Later, however, $L P$ is presented as a part of $P L$, namely the principles that should govern the foreign policy of liberal peoples ( $L P$ 82), and as part of $P L$ the doctrine on just war must be political. 
This silent tension in $L P$ is supplemented by a slide from an ideal doctrine to a realistic doctrine. Rawls presents $L P$ as an ideal conceptual theory, but since conditions are not ideal in the real world, well ordered people need a 'non-ideal theory' to guide them in how to treat 'nonwell-ordered' peoples ( $L P$ 89). This non-ideal theory should then consider which policies and courses of action can be morally justified and are politically possible. It is in this context the question of just war arises in $L P$.

When it comes to jus ad bellum, Rawls states as both a fact and a norm that well-ordered people do not wage war against each other ( $L P$ 94). The controversial point is that he nevertheless allows for military interventions in sovereign states in two cases. First, interventions are allowed, if a not-well ordered 'states expansionist aims threaten the security and free institutions of well ordered regimes and bring about the war'. Second, if human rights are violated, and if all other means have been tried, intervention is 'acceptable and called for' ( $L P$ 94), making intervention in this case not just a right, but a duty.

Rawls is careful to distinguish between outlaw states and the people, who must suffer living within the sphere of outlaw power. But the parties addressed in $L P$ are not the peoples repressed by outlaw states, but those well ordered peoples, who witness the suppression of the notwell-ordered people. Just as Rawls in $P L$ does not support individual civil disobedience, there is in $L P$ no mention of the right of any people to overthrow their own government under certain conditions, as it is stated in the American constitution. The weight is put on a duty of well ordered people to assist not-well-ordered people by a military intervention that will overthrow the outlaw state of the latter.

When it comes to the conduct of war, jus in bello what is controversial is Rawls' admissions to realist politics concerning non-combatants. In a war against non-well-ordered peoples Rawls allows for a 'supreme emergency exemption', which in extreme cases can justify mass 
destruction of civilian targets including the civilians themselves ( $L P$ 989). Rawls admit such cases as hard, but put his faith in the ideal of the 'statesman'. This, however, seems like a very weak conceptual solution for a an international law, which should express liberal democratic principles.

In $L P$ Rawls makes international relations in principle asymmetrical: Some peoples are well ordered, some are not, and only the former have the right and sometimes even a duty to teach the latter a military lesson. Non-provoked preventive war and civilian massacres can be legitimate, although only for well-ordered people against non-well-ordered people. Again Rawls is in line with official US vocabulary, where some states are labelled as 'pariah', 'rogues' and 'outlaws'.

4.

In $\mathrm{ToJ}$ it can be a duty for an individual to refuse carrying out illegitimate actions in a war. In $L P$ it can be a duty of peoples to conduct war in order to defend human rights. The first perspective is comprehensive, moral, individual, and peaceful, the second is political, collective, and belligerent. The first is seen from an ordinary member of society, the second from the ruler. By talking of people in stead of states, however, this contrast is blurred.

The slide from $T o J$ to $L P$ is clearly authoritarian. In $L P$ both hierarchy and democracy can be well-ordered and thus legitimate political structures, and Rawls does not give any reasons to suspect that a conception of an outlaw state of non-well-ordered people could be due to errors, ideological blindness, mass-media hysteria, or government propaganda.

Some might find this critique exaggerated. But Rawls consistently endorse the vocabulary of contemporary US governments. And when it comes to handling the current situation, Rawls put his faith in same conceptual instruments as the neo-conservatives, who ideologically are responsible for the interventions in Afghanistan and Iraq. First, there is 
the ideal of the statesman, where Rawls's examples are two favourites also celebrated by neo-conservatives, namely Churchill and Lincoln. ${ }^{5}$ Second, the idea of 'supreme emergency exemption' is very close to an idea also praised by neo-conservative, namely Carl Schmitt's infamous idea of the 'exception'. ${ }^{6}$

In sum, Rawls's Law of peoples leaves too much room for the classical principle, 'might is right'.

${ }^{5}$ See, for instance, Anne Norton: Leo Strauss and the Politics of American Empire, New Haven \& London: Yale University Press, 2004, pp. 127 ff.. ${ }^{6}$ See, for instance, Michael Hardt \& Antonio Negri: Empire, Cambridge, Mass.: Harvard University Press, 2000, pp. 16 f.. 